\title{
$\left[{ }^{3} \mathrm{H}\right]$-OUABAIN BINDING TO PERIPHERAL ORGANS OF CATS: EFFECT OF ETHANOL
}

\author{
SHAILESH P. BANERJEE \& VIRENDRA K. SHARMA
}

Department of Pharmacology and Toxicology, University of Rochester School of Medicine and Dentistry, Rochester, New York 14642, U.S.A.

1 The specific $\left[{ }^{3} \mathrm{H}\right]$-ouabain binding to microsomal fractions derived from cat heart, liver, spleen, and kidney increased significantly following chronic administration of ethanol.

2 Since ouabain binds exclusively to cell membrane $\left(\mathrm{Na}^{+}+\mathrm{K}^{+}\right)$-adenosine triphosphatase $\left(\left(\mathrm{Na}^{+}+\mathrm{K}^{+}\right)\right.$-ATPase), these results provide evidence for an increase in number of $\left(\mathrm{Na}^{+}+\mathrm{K}^{+}\right)$ATPase macromolecules during chronic alcoholism.

3 The importance of the increase in number of $\left(\mathrm{Na}^{+}+\mathrm{K}^{+}\right)$-ATPase molecules in the adaptive increase in ethanol metabolism and cardiac myopathy in chronic alcoholism is discussed.

\section{Introduction}

Chronic treatment of rats with ethanol has been shown to increase the rate of ethanol metabolism in vivo (Mendelson, Stein \& Mello, 1965; Hawkins, Kalant \& Khanna, 1966; Mezey \& Tobon, 1971; Videla, Bernstein \& Israel, 1973) and in vitro (Videla \& Israel, 1970), and also to increase the rate of oxygen consumption by the liver in vitro (Videla et al., 1973; Bernstein, Videla \& Israel, 1973) and in the perfused liver (Thurman, McKenna \& McCaffrey, 1976). Israel and his associates have demonstrated that following chronic treatment with ethanol, an enhancement of the activity of $\left(\mathrm{Na}^{+}+\mathrm{K}^{+}\right)$-adenosine triphosphatase $\left(\left(\mathrm{Na}^{+}+\mathrm{K}^{+}\right)\right.$-ATPase $)$in liver may be observed (Bernstein et al., 1973; Israel, Videla \& Bernstein, 1975). This has been suggested to lead to increased utilization of ATP and a resultant drop in the phosphorylation potential (ATP/ADP $\times$ Pi) which normally regulates the rate of mitochondrial oxidation (Chance \& Maitra, 1963). This drop in the phosphorylation potential stimulates mitochondrial respiration, which in turn oxidizes NADH and supplies more $\mathrm{NAD}^{+}$for the alcohol dehydrogenase reaction (Bernstein, Videla \& Israel, 1974; Israel et al., 1975; Thurman et al., 1976).

Although stimulation of $\left(\mathrm{Na}^{+}+\mathrm{K}^{+}\right)$-ATPase activity following chronic administration of ethanol has been demonstrated, it is not known whether this increase is due to synthesis of new $\left(\mathrm{Na}^{+}+\mathrm{K}^{+}\right)$-ATPase molecules or activation of this enzyme system. Furthermore, no information is available on the effect of chronic ethanol ingestion on $\left(\mathrm{Na}^{+}+\mathrm{K}^{+}\right)$-ATPase activity in peripheral organs other than liver. Avail- ability of $\left[{ }^{3} \mathrm{H}\right]$-ouabain, which is a specific inhibitor of monovalent cation transport across the cell membrane, provides a convenient method to estimate the number of $\left(\mathrm{Na}^{+}+\mathrm{K}^{+}\right)$-ATPase molecules (Schwartz, Lindenmayer \& Allen, 1975). The purpose of this paper is to describe the alteration of specific $\left[{ }^{3} \mathrm{H}\right]$-ouabain binding to microsomal suspensions of different peripheral tissues of cats following chronic ethanol administration.

\section{Methods}

Adult male cats weighing 2.5 to $3.5 \mathrm{~kg}$ were used. Four experimental cats were given a $20 \%(\mathrm{v} / \mathrm{v})$ solution of ethanol by stomach tube in doses of $1.5 \mathrm{~g} / \mathrm{kg}$ body weight twice a day for five weeks, as described by Knox, Perrin \& Sen (1972). Four control animals received similar volumes of $0.9 \% \mathrm{w} / \mathrm{v} \mathrm{NaCl}$ solution (saline). None of the animals received ethanol or saline for $36 \mathrm{~h}$ before they were killed by an overdose of sodium pentobarbitone. The liver, kidney, heart, and spleen were rapidly removed and chilled in icecold saline. The different tissues were separately homogenized in 20 volumes of $0.25 \mathrm{M}$ sucrose containing $100 \mathrm{~mm} \mathrm{NaCl}$ and $0.5 \mathrm{mM} \mathrm{MgSO}_{4}$ with a Brinkman Polytron (Model PT-10ST). The whole homogenate was centrifuged for $10 \mathrm{~min}$ at $1000 \mathrm{~g}$. The pellet was discarded, and the supernatant fraction was centrifuged for $10 \mathrm{~min}$ at $7710 \mathrm{~g}$. The second pellet was also discarded, and the supernatant fluid was centrifuged for $60 \mathrm{~min}$ at $100,000 \mathrm{~g}$ at $4^{\circ} \mathrm{C}$. The final pellet 
was suspended ( 2 to $5 \mathrm{mg}$ protein per $\mathrm{ml}$ ) in Tris- $\mathrm{HCl}$ (pH 7.4 at $37^{\circ} \mathrm{C}, 50 \mathrm{~mm}$ ) to obtain the crude microsomal fraction.

The assay for specific binding of $\left[{ }^{3} \mathrm{H}\right]$-ouabain to crude microsomal suspensions has been described before (Banerjee \& Bosmann, 1976; Sharma \& Banerjee, 1977a). Total binding was estimated in the presence of $1 \mathrm{mM} \mathrm{Mg}^{2+}, 1 \mathrm{mM} \mathrm{Na} \mathrm{NTP}_{2}, 0.1 \mathrm{M} \mathrm{Na}^{+}$, and $0.2 \mathrm{ml}$ of tissue suspension in a total volume of 2 $\mathrm{ml}$ at $37^{\circ} \mathrm{C}$ for 30 minutes. Specific $\left[{ }^{3} \mathrm{H}\right]$-ouabain binding to various microsomal suspensions reached equilibrium in $10 \mathrm{~min}$ or less and remained in steady state for $60 \mathrm{~min}$ or more. The concentration of $\left[{ }^{3} \mathrm{H}\right]$-ouabain ranged between 0.08 and $0.64 \mu \mathrm{M}$. Corrections were made for non-specific accumulation of radioactivity by assaying parallel incubations in which ATP and $\mathrm{Mg}^{2+}$ were omitted from the reaction mixtures. In the presence of $\mathrm{Na}^{+}$and the absence of nucleotide, such as ATP, $\left[{ }^{3} \mathrm{H}\right]$-ouabain does not bind to the $\left(\mathrm{Na}^{+}+\mathrm{K}^{+}\right)$-ATPase enzyme system (Schwartz et al., 1975). The nonspecific accumulation of radioactivity was generally less than $12 \%$ of the total binding. The kinetic parameters such as dissociation constants $\left(K_{\mathrm{D}}\right)$ and maximal number of binding sites $\left(B_{\max }\right)$ were determined both from reciprocal plots and Scatchard analysis (Scatchard, 1949). Slopes and intercepts of the lines were determined by the method of least squares. $\left[{ }^{3} \mathrm{H}\right]$-ouabain (specific activity $14.4 \mathrm{Ci} / \mathrm{mmol}$ ) was obtained from New England Nuclear, Boston, Mass, U.S.A., and found to be greater than $97 \%$ pure, as determined by thin layer chromatography on silica gel using chloroform:methanol:water $(65: 30: 5)$.

\section{Results}

The specific $\left[{ }^{3} \mathrm{H}\right]$-ouabain binding to microsomal fractions derived from control cat heart, liver, spleen, and kidney is shown in Table 1 . The specific $\left[{ }^{3} \mathrm{H}\right]$-ouabain binding to heart and liver microsomal fractions was similar. On the other hand, the specific $\left[{ }^{3} \mathrm{H}\right]$-ouabain binding to kidney and spleen membrane preparations were respectively four times, and one-third of, that observed with the liver microsomal fraction (Table 1). These results are similar to the $\left(\mathrm{Na}^{+}+\mathrm{K}^{+}\right)$-dependent ATPase activities previously observed in various perpiheral tissues of cats (Bonting, Simon \& Hawkins, 1961). Chronic treatment of cats with ethanol resulted in a marked increase in specific $\left[{ }^{3} \mathrm{H}\right]$-ouabain binding to microsomal fractions of heart, liver, spleen, and kidney, i.e., to 165 , 189,228 and $159 \%$ of control values, respectively. Thus, the percentage increases in specific $\left[{ }^{3} \mathrm{H}\right]$-ouabain binding in the various peripheral organs of the treated cats were similar, despite considerable variation in specific binding of control cat preparations (Table 1).

The results described so far demonstrate that chronic administration of ethanol increases specific $\left[{ }^{3} \mathrm{H}\right]$-ouabain binding in all four peripheral tissues examined. This increase may be due to changes in the apparent affinity of $\left[{ }^{3} \mathrm{H}\right]$-ouabain for membrane preparations or alterations in the number of specific binding sites on the cell surface. Thus the equilibrium dissociation constand $\left(K_{\mathrm{D}}\right)$ and the density of specific $\left[{ }^{3} \mathrm{H}\right]$-ouabain binding sites $\left(B_{\max }\right)$ in different microsomal fractions were determined by Scatchard (1949) and reciprocal plots. Scatchard and reciprocal plots of the data derived from heart, liver, and kidney preparations from control and ethanol-treated cats are shown in Figures 1 to 3. The results are consistent with the idea that there is only one class of high affinity binding sites in all the preparations examined in the present study. The equilibrium dissociation constant and maximal number of binding sites

Table $1\left[{ }^{3} \mathrm{H}\right]$-ouabain binding to microsomal fractions obtained from peripheral organs of cats

\begin{tabular}{|c|c|c|c|c|c|c|}
\hline \multirow[b]{2}{*}{ Organ } & \multicolumn{6}{|c|}{$\left[^{3} \mathrm{H}\right]$-ouabain binding (pmol/mg protein) } \\
\hline & Total & Nonspecific & $\begin{array}{l}\text { Specific } \\
\text { binding }\end{array}$ & Total & Nonspecific & $\begin{array}{l}\text { Specific } \\
\text { binding }\end{array}$ \\
\hline $\begin{array}{l}\text { Heart } \\
\text { Liver } \\
\text { Kidney } \\
\text { Spleen }\end{array}$ & $\begin{array}{l}0.51 \pm 0.05 \\
0.58 \pm 0.04 \\
1.94 \pm 0.11 \\
0.19 \pm 0.01\end{array}$ & $\begin{array}{l}0.14 \pm 0.01 \\
0.22 \pm 0.02 \\
0.29 \pm 0.02 \\
0.06 \pm 0.004\end{array}$ & $\begin{array}{l}0.37 \\
0.36 \\
1.64 \\
0.13\end{array}$ & $\begin{array}{l}0.83 \pm 0.05 \\
1.12 \pm 0.07 \\
2.69 \pm 0.16 \\
0.40 \pm 0.01\end{array}$ & $\begin{array}{l}0.20 \pm 0.01 \\
0.49 \pm 0.03 \\
0.35 \pm 0.02 \\
0.14 \pm 0.009\end{array}$ & $\begin{array}{l}0.63^{*} \\
0.63^{*} \\
2.34^{*} \\
0.26^{*}\end{array}$ \\
\hline
\end{tabular}

The procedure for the measurement of $\left[{ }^{3} \mathrm{H}\right]$-ouabain is described in the Methods section. The concentration of $\left[{ }^{3} \mathrm{H}\right]$-ouabain was $80 \mathrm{~nm}$ and values are means \pm standard errors of 4 separate experiments, each in triplicate.

* Significantly different from control, $P<0.001$. 

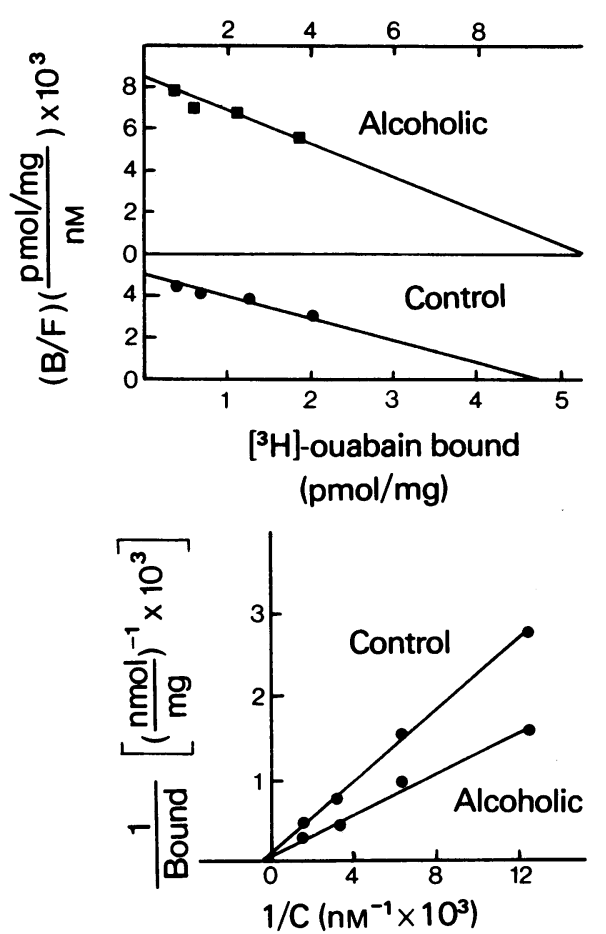

Figure 1 Scatchard analysis and reciprocal plots of specific $\left[{ }^{3} \mathrm{H}\right]$-ouabain binding to cardiac microsomal suspension derived from control and chronic ethanol-treated cats. Specific $\left[{ }^{3} \mathrm{H}\right]$-ouabain binding to cardiac microsomal preparation obtained from control and chronically ethanol-treated cats was measured as described in the Methods section. Abscissae for chronic ethanol-treated and control cat hearts for Scatchard plots are at the top and bottom of the figure, respectively. The correlation coefficient, $r$, was 0.91 or greater.

obtained from Figures 1-3 are provided in Table 2 . Although chronic administration of ethanol had little effect on the dissociation constant of ouabain for particulate fractions derived from kidney and heart, the apparent affinity of hepatic $\left(\mathrm{Na}^{+}+\mathrm{K}^{+}\right)$-ATPase for ouabain changed from $5 \mu \mathrm{M}$ in control preparations to $1 \mu \mathrm{M}$ in ethanol-treated cat liver preparations. The densities of specific $\left[{ }^{3} \mathrm{H}\right]$-ouabain binding sites increased in heart and kidney and decreased in liver microsomal suspensions following chronic administration of ethanol (Table 2).

Recently, we measured the distribution of $\left(\mathrm{Na}^{+}+\mathrm{K}^{+}\right)$-ATPase in sympathetic nerve endings and their end organs (Sharma \& Banerjee, 1977b). More than $80 \%$ of the total number of specific $\left[{ }^{3} \mathrm{H}\right]$-ouabain binding sites in heart preparations was localized at the sympathetic nerve endings. In contrast, chemical sympathectomy did not decrease
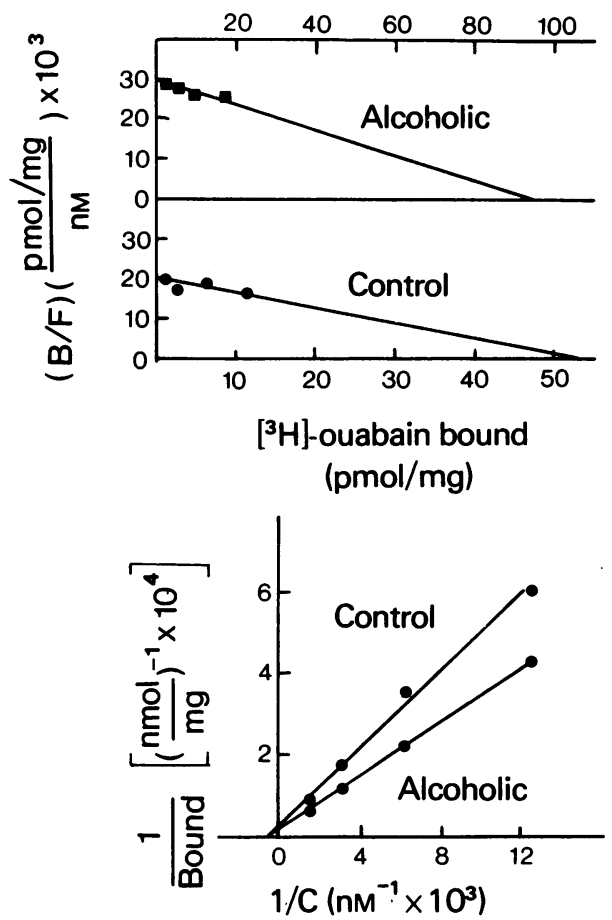

Figure 2 Scatchard and reciprocal plots of specific $\left[{ }^{3} \mathrm{H}\right]$-ouabain binding to microsomal preparation obtained from kidney of control and chronic ethanol-treated cats. The methods for the measurement of specific $\left[{ }^{3} \mathrm{H}\right]$-ouabain binding and administration of ethanol are described in the text. Abscissae for chronic ethanol-treated and control cat kidneys for Scatchard plots are at the top and bottom of the figure, respectively. The correlation coefficient, $r$, was 0.82 or greater.

specific $\left[{ }^{3} \mathrm{H}\right]$-ouabain binding in kidney or spleen microsomal suspensions (Sharma \& Banerjee, 1977b). This observation suggests that most of the specific $\left[{ }^{3} \mathrm{H}\right]$-ouabain binding sites in kidney or spleen preparations are localized at the secretory cells of these organs. Nevertheless, the ability of ethanol to increase the density of $\left(\mathrm{Na}^{+}+\mathrm{K}^{+}\right)$-ATPase in heart and kidney microsomal suspensions after chronic administration suggests that this drug enhances the number of ouabain binding sites in neuronal as well as non-neuronal cells of peripheral organs.

\section{Discussion}

There is some evidence that the adaptive increase in ethanol metabolism in chronic alcoholism may be due in part to increased production of $\mathrm{NAD}^{+}$. This in- 


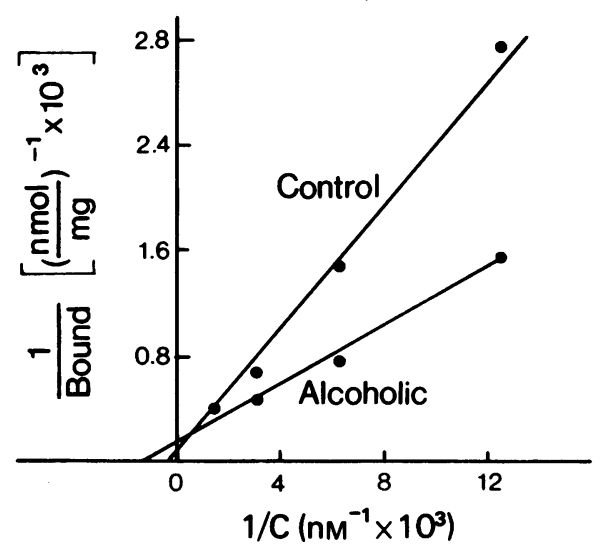

Figure 3 Reciprocal plots of specific $\left[{ }^{3} \mathrm{H}\right]$-ouabain binding to liver microsomal suspension derived from control and chronic ethanol-treated cats. Specific $\left[{ }^{3} \mathrm{H}\right]$-ouabain binding to microsomal preparation derived from control and chronically ethanoltreated cats was measured as described in the Methods section. The correlation coefficient, $r$, was 0.99 for both lines.

crease in $\mathrm{NAD}^{+}$production is believed to be a direct consequence of increased $\left(\mathrm{Na}^{+}+\mathrm{K}^{+}\right)$-ATPase activity of liver microsomes induced by chronic administration of ethanol (Israel et al., 1975; Thurman et al., 1976). Biochemical mechanisms for the enhancement of $\left(\mathrm{Na}^{+}+\mathrm{K}^{+}\right)$-ATPase activity during chronic alcoholism are not known. Ouabain is a specific inhibitor of $\left(\mathrm{Na}^{+}+\mathrm{K}^{+}\right)$-ATPase and specific $\left[{ }^{3} \mathrm{H}\right]$-ouabain binding to a microsomal fraction has been shown to be exclusively associated with the larger subunit of $\left(\mathrm{Na}^{+}+\mathrm{K}^{+}\right.$)-ATPase (Hegyvary, 1975). Therefore, specific $\left[{ }^{3} \mathrm{H}\right]$-ouabain binding may be used to estimate the number of functional $\left(\mathrm{Na}^{+}+\mathrm{K}^{+}\right)$-ATPase molecules (Schwartz et al.,
1975). Results of the present investigation clearly show an increase in number of functional $\left(\mathrm{Na}^{+}+\mathrm{K}^{+}\right)$-ATPase molecules on the microsomal fraction of some peripheral organs, such as heart and kidney, of cats after chronic ethanol ingestion (Table 2; Figures 1 and 2). The increase in number of $\left(\mathrm{Na}^{+}+\mathrm{K}^{+}\right)$-ATPase molecules in chronic alcoholism may be due to increased net synthesis of $\left(\mathrm{Na}^{+}+\mathrm{K}^{+}\right)$-ATPase molecules or exposure of 'nonfunctional' enzyme molecules as a result of conformational change of cell surface membranes. The present observations are not sufficient to distinguish between these two possibilities.

An interesting finding in the present study is the decrease in maximal number of ouabain binding sites in liver membrane preparations from ethanol-treated cats (Table 2). This decrease may be related to nonspecific hepatotoxicity of ethanol. Although the maximal number of ouabain binding sites is decreased in cat liver microsomal suspensions obtained from the ethanol-treated group, the apparent affinity for ouabain is increased five-fold over control (Figure 3 and Table 2). The molecular mechanism for this augmentation of apparent affinity is not known. Nevertheless, it is interesting to point out that triiodothyronine, which is known to activate thermogenic organ $\left(\mathrm{Na}^{+}+\mathrm{K}^{+}\right)$-ATPase (Edelman, 1976), appears to regulate specific $\left[{ }^{3} \mathrm{H}\right]$-ouabain binding sites by the alterations of dissociation constants and not by changes in the maximal number of binding sites in rat heart and rat skeletal muscle membrane preparations (Banerjee \& Sharma, 1977). These observations raise the possibility that increased production of $\mathrm{NAD}^{+}$or augmentation of $\left(\mathrm{Na}^{+}+\mathrm{K}^{+}\right)$-ATPase activity found in the liver membrane preparation from cats chronically treated with ethanol (Thurman et al., 1976) may be mediated in part by thyroid hormones.

Chronic alcoholism is known to cause morphologi-

Table 2 Apparent affinities and binding capacities of $\left[{ }^{3} \mathrm{H}\right]$-ouabain in some peripheral organs of cats

\begin{tabular}{|c|c|c|c|c|c|}
\hline \multirow[b]{2}{*}{ Organ } & \multirow[b]{2}{*}{$\begin{array}{l}\text { Kinetic } \\
\text { analysis }\end{array}$} & & \multicolumn{2}{|c|}{ Ethanol-treated } \\
\hline & & $\begin{array}{c}K_{D} \\
(\mu M)\end{array}$ & $\begin{array}{c}B_{\max } \\
(p \operatorname{mol} / \mathrm{mg})\end{array}$ & $\begin{array}{c}K_{\mathrm{D}} \\
(\mu M)\end{array}$ & $\begin{array}{c}B_{\max } \\
(p m o l / m g)\end{array}$ \\
\hline $\begin{array}{l}\text { Heart } \\
\text { Kidney } \\
\text { Liver }\end{array}$ & $\begin{array}{l}\text { Scatchard } \\
\text { Scatchard } \\
\text { Scatchard }\end{array}$ & $\begin{array}{l}0.94 \\
2.70 \\
5.00\end{array}$ & $\begin{array}{r}4.75 \\
55.00 \\
22.55\end{array}$ & $\begin{array}{l}1.25 \\
3.10 \\
1.00\end{array}$ & $\begin{array}{r}10.25 \\
95.00 \\
9.25\end{array}$ \\
\hline $\begin{array}{l}\text { Heart } \\
\text { Kidney } \\
\text { Liver }\end{array}$ & $\begin{array}{l}\text { Reciprocal } \\
\text { Reciprocal } \\
\text { Reciprocal }\end{array}$ & $\begin{array}{l}1.66 \\
2.30 \\
5.00\end{array}$ & $\begin{array}{r}6.73 \\
23.80 \\
25.00\end{array}$ & $\begin{array}{l}1.66 \\
2.30 \\
1.00\end{array}$ & $\begin{array}{l}13.25 \\
33.30 \\
10.10\end{array}$ \\
\hline
\end{tabular}

The equilibrium dissociation constant $\left(K_{D}\right)$ and maximal number of binding sites ( $B_{\max }$ ) were estimated from Scatchard and reciprocal plots. The microsomal fractions were assayed with various concentrations of $\left[{ }^{3} \mathrm{H}\right]$-ouabain, as described in the text. The values are averages of 12 determinations. 
cal, functional, and metabolic changes in the heart (Alexander, 1968; Gould, 1970). However, the precise mechanism whereby ethanol induces myocardial damage is not known. The increased accumulation of triglycerides or toxic metabolites of ethanol and alterations in heart noradrenaline metabolism have been postulated as causes of alcoholic cardiomyopathy (Alexander, 1968; Gould, 1970). A major pathway for the metabolism of noradrenaline is the transport of the neurotransmitter into the sympathetic nerve endings (Iversen, 1975). There is some evidence that the noradrenaline transport system is associated with the $\left(\mathrm{Na}^{+}+\mathrm{K}^{+}\right)$-ATPase localised in the plasma

\section{References}

ALEXANDER, C.S. (1968). The concept of alcoholic myocardiopathy. Med. Clin. North Amer. 52, 1183-1191.

BANERJEE, S.P. \& BOSMANN, H.B. (1976). Rubidium transport and ouabain binding in normal and virally transformed mouse fibroblasts. Exp. Cell Res. 100, 153-158.

BANERJEE, S.P. \& SHARMA, V.K. (1977). Effect of thyroid hormone on specific $\left[{ }^{3} \mathrm{H}\right]$ ouabain binding to rat heart and skeletal muscle membrane. Pharmacologist, 19, 446.

BERNSTEIN, J., VIDELA, L. \& ISRAEL, Y. (1973). Metabolic alterations produced in the liver by chronic ethanol administration; changes related to energetic parameters of the cell. Biochem. J., 134, 515-521.

BERNSTEIN, J., VIDELA, L. \& ISRAEL, Y. (1974). Role of the sodium pump in the regulation of liver metabolism in experimental alcoholism. Ann. N.Y. Acad. Sci., 242, $560-572$.

BONTING, S.L., SIMON, K. \& HAWKINS, N.M. (1961). Studies on sodium-potassium-activated adenosine triphosphatase. I. Quantitative distribution in several tissues of the cat. Archs Biochem. Biophys., 95, 416-423.

CHANCE, B. \& MAITRA, P.K. (1963). Determination of the intracellular phosphate potential of ascites cells by reversed electron transfer. In Control Mechanisms in Respiration and Fermentation. ed. Wright, B. pp. 307-332. New York: The Ronald Press Co.

EDELMAN, I.S. (1976). Transition from the poikilotherm to the homeotherm: possible role of sodium transport and thyroid hormone. Fedn Proc., 35, 2180-2184.

GOULD, L. (1970). Cardiac effects of alcohol. Am. Heart J., 79, 422-429.

HAWKINS, R.D., KALANT, H. \& KHANNA, J.M. (1966). Effects of chronic intake of ethanol on rate of ethanol metabolism. Can. J. Physiol. Pharmac., 44, 241-257.

HEGYVARY, C. (1975). Covalent labeling of the digitalisbinding component of plasma membranes. Mol. Pharmac., 11, 588-594.

ISRAEL, Y., VIDELA, L. \& BERNSTEIN, J. (1975). Liver hypermetabolic state after chronic ethanol consumption: hormonal interrelations and pathogenic implications. Fedn. Proc., 34, 2052-2059.

IVERSEN, L.L. (1975). Uptake processes for biogenic amines. In Handbook of Psychopharmacology, Vol. III. ed. Iversen, L.L., Iversen, S.D. \& Snyder, S.H. pp. 381-442. New York: Plenum Press. membrane of the sympathetic nerve endings (Sharma \& Banerjee, 1977a). The increase in $\left(\mathrm{Na}^{+}+\mathrm{K}^{+}\right)$ ATPase activity of sympathetic nerve endings in the heart after chronic ethanol ingestion may modify noradrenaline metabolism and thus contribute to myocardial pathogenesis (Rossi \& Oliveira, 1976).

This work was supported in part by United States Public Health Service Grant HL-18185 and a grant-in-aid from the American Heart Association, with funds contributed in part by the New York Heart Association. V.K.S. is supported by a fellowship from the Genesee Valley Heart Association.

KNOX, W.H., PERRIN, R.G. \& SEN, A.K. (1972). Effect of chronic administration of ethanol on $\left(\mathrm{Na}^{+}+\mathrm{K}^{+}\right)$-activated ATPase activity in six areas of the cat brain. J. Neurochem. 19, 2881-2884.

MENDELSON, J.H., STEIN, S. \& MELLO, N.K. (1965). Effects of experimentally induced intoxication on metabolism of ethanol-1- ${ }^{14} \mathrm{C}$ in alcoholic subjects. Metab. (Clin. Exp.), 14, 1255-1266.

MEZEY, E. \& TOBON, F. (1971). Rates of ethanol clearance and activities of the ethanol-oxidizing enzymes in chronic alcoholic patients. Gastroenterology, 61, 707-715.

ROSSI, M.A. \& OLIVEIRA, J.S.M. (1976). Effect of prolonged ethanol administration on the noradrenaline levels of rat heart. Eur. J. Pharmac., 40, 187-190.

SCATCHARD, G. (1949). The attraction of proteins for small molecules and ions. Ann. N. Y. Acad. Sci. 51, 660-672.

SCHWARTZ, A., LINDENMAYER, G.E. \& ALLEN, J.C. (1975). The sodium-potassium adenosine triphosphatase: pharmacological, physiological and biochemical aspects. Pharmac. Rev., 27, 3-134.

SHARMA, V.K. \& BANERJEE, S.P. (1977a). Inhibition of $\left[{ }^{3} \mathrm{H}\right]$ noradrenaline uptake in peripheral organs of some mammalian species by ouabain. Eur. J. Pharmac., 41, 417-429.

SHARMA, V.K. \& BANERJEE, S.P. (1977b). 6-Hydroxydopamine effect on specific $\left[{ }^{3} \mathrm{H}\right]$ ouabain binding to some sympathetically innervated organs of the cat. Mol. Pharmac., 13, 796-804.

THURMAN, R.G., McKENNA, W.R. \& McCAFFREY, T.B. (1976). Pathways responsible for the adaptive increase in ethanol utilization following chronic treatment with ethanol: inhibitor studies with the hemoglobin-free perfused rat liver. Mol. Pharmac., 12, 156-166.

VIDELA, L. \& ISRAEL, Y. (1970). Factors that modify the metabolism of ethanol in rat liver and adaptive changes produced by its chronic administration. Biochem. J., 118, 275-281.

VIDELA, L., BERNSTEIN, J. \& ISRAEL, Y. (1973). Metabolic alterations produced in the liver by chronic ethanol administration. Increased oxidative capacity. Biochem. $J ., 134,507-514$.

(Received February 8, 1977. Revised July 7, 1977.) 